\title{
THE FOREST-PATH OF LAW AND THE WOLF- BELLY OF JUSTICE: LEGAL THEORY AND FAIRY TALE
}

\author{
David Gurnham, Lecturer in Law, University of Manchester
}

\section{Introduction}

European Fairy tales have evolved from oral folk tales and represent all manner of social, historical, political and moral purposes and agendas to their many readers and commentators of all ages. Of the many possible reasons for returning to these old stories, mine is that they have something very interesting to contribute to debates on the idea of 'justice'. Contemporary readings do not agree on the moral significance of the genre, although prima facie a morally conservative idea of justice is rarely more apparent than in the fairy tales collected by and published initially in early nineteenth century Germany by the Brothers Grimm. ${ }^{1}$ This article first rehearses the conservative view of fairy tales, which holds that the difference between heroes and villains are represented by a conceptual distinction between interior (home) and exterior (outside). On this view, villains such as wicked stepmothers and wolves appear as physically and morally peripheral to the societies which they come to threaten. Such a distinction, we may think, prescribes a fairly clear definition of justice and injustice, and at least for Grimm and others who wrote the tales down, this is deliberately so. But of course, the tales were not the original creations of the Grimms, Charles Perrault ${ }^{2}$ or Giambattista Basile, ${ }^{3}$ all of whom are considered here. The significance of their work in collecting and publishing existing popular peasant folk tales was to make the stories available in a standard written form that was suitable for a contemporary audience. This article argues that reading the tales in the context of this oral folk history reveals a much more complex and uncertain moral landscape. The tales speak of a darker and more interesting view of justice lurking within the apparently secure moral distinction between 'home' and 'outside'. They warn that danger and violence is not conceptually separate to places (and concepts) that we thought were safe. Specifically, the tales narrate the inter-generational conflicts involved in family life and warn about the dangers of child abuse and incest within the home.

\section{The Moral Conservatism of Fairy Tales}

\section{Bourgeois values and gender stereotypes}

At its most basic, the fairy tale idea of justice apparent from the collections of the Grimms, Perrault and the Italian Giambasttista Basile is that in the end

1 See J.L.C. \& W.C. Grimm, Grimm's Fairy Tales, trans. L. Crane (Wordsworth Classics, 1993)

2 C. Perrault, Tales from Perrault (Oxford University Press, 1988); first published in France in 1697.

3 G. Basile, The Pentameron, trans. Sir R. Burton (Spring Books, 1957) 
everyone gets what they deserve. Reading the tales as an illustration of this principle, it is difficult not to discern a natural order associated with ideas of gender and justice. It is well known that the Grimm brothers collected folk tales for their collection under conditions of economic hardship and French military occupation of their home town of Kassel. Having themselves been born into a frugal Protestant family, the Grimms worked with the belief that the old folk tales represented an ideal German culture - a vital form which they could use to educate the children of the middle classes in the Calvinist virtues of diligence, industry, honesty, order and cleanliness. ${ }^{4}$ Of course, there was nothing distinctly German about the stories - various versions (some of which are examined here) existed all over Europe - but the Grimms believed that the spirit of the German people was captured in "natural and pure forms of culture". 5 They feared that this spirit was in danger of being lost underneath the development of the more "refined" culture of the Renaissance and Enlightenment, ${ }^{6}$ and their project of collecting and reinvigorating old folk tales would preserve the purity of traditional German culture. ${ }^{7}$ Zipes's own interpretation of Grimm is grounded in both history and psychoanalysis. According to Zipes, Grimm's resurrection of old folk tales forms was "based on a desire to resurrect the authority of their father and his heritage to regain a lost, untarnished home or realm". 8 Zipes suggests that it was the loss of the Fatherland following Prussia's defeat by Napoleon and dissolution of the Holy Roman Empire in 1806 that motivated the Grimms to reflect on the domestic concerns in their versions of the tales they collected. Wounded by foreign occupation of the Empire, the Grimms reflected on the need for a home, loyalty between family relations, the punishment of evil, achievement of contentment through simple hard work, perseverance and an acceptance of the rule of the Father. ${ }^{9}$ In teaching the difference between right and wrong, the tales present an idea of justice as bound up in bourgeois ideals of industry, home and specific gender roles. Thus, Grimm's tales are patriarchy personified: Father, Fatherland, patriarchal family values. Marina Warner, to whom we shall return, also favours an historical approach to reading fairy and folk tales. She reads the narratives of wicked stepmothers, not as representative of Oedipal anxieties, but as the realistic voice of women of seventeenth and eighteenth century Europe trying to articulate their vulnerability in their specific social and legal system. ${ }^{10}$

Zipes regards Grimm's tales as deeply conservative and as such not entirely suitable for a modern audience. ${ }^{11}$ Other commentators share the view that gender and justice are inextricably linked in fairy tales generally. Steven Swann Jones argues that the conservatism of fairy tales is demonstrated

4 Zipes, J. The Brothers Grimm: from enchanted forests to the modern world (Routledge, 1988) p.34

5 ibid., at p.32. However, it should be noted that Germany did not exist as a unified nation state until 1871, following defeat of France in the Franco-Prussian war.

6 ibid.

7 ibid., at p.33

8 ibid., at p.34

9 ibid., at pp.37-9

10 M. Warner, M. From the Beast to the Blonde: On Fairytales (Chatto \& Windus, 1994) Chap.14, pp.218-240

11 Zipes, above, n.4 at p.42 
through their themes of social instruction and cosmology. The tales are intended to encourage bourgeois values of "industry and moral virtue", and characters that display these qualities are rewarded with material goods. ${ }^{12}$ At the same time, the tales naturalise earthly values by providing an account of how the universe is. Fairy tales often involve the protagonist being called upon to solve some problem, pass a test or survive some ordeal in order to prove their worth. Male protagonists are encouraged to take the initiative, discover things and solve problems actively. ${ }^{13}$ Female protagonists by contrast find success in passivity and acceptance of their proper place within the family home. ${ }^{14}$ Indeed, the home, in contrast to the forest, is generally depicted as the reward for characters that behave in the proper way. The bourgeois idea of home as a place of safety, comprising its own patriarchal moral and legal order, is a neat and easy metaphor for the moral certainties that fairy tales appear to herald. Hansel and Gretel (in Grimm's tale of the same name) are clearly good children, notwithstanding their greed for sweets, because they are possessed of no greater desire than to find their way home. The story of their unjust expulsion from home by a selfish stepmother is a warning about the need to protect the integrity of home from things that ought to remain outside in the woods. Hansel and Gretel is typical of the genre in this respect. The moral culpability of the stepmother is that she has usurped not only the mother's role, but the father's as well as master of the house. The threat she poses to the patriarchal order of the home and her wilfulness marks her out as archetypal villain. The world is full of dangers, we are warned, and these must be prevented from entering the home and disrupting its moral order.

Gender and justice are so closely linked, that it is possible to say that characteristics favoured in males would generally constitute wickedness in a female. Sandra Gilbert argues that the options presented to female characters are so narrow as to constitute an imperative. For example in Snow White, there is clearly only one viable option for the female protagonist: she must strive become a dutiful wife and mother ${ }^{15}$ or else endure the humiliating end suffered by her step mother who did not. As we shall see in detail below, the femininity of fairy tales reflects a conservative attitude towards the moral education of young women. In its immature form, femininity is selfdestructive in its naïve curiosity, narcissism and sexuality, and stands in need of correction and protection from its own childish desires. Hence, female characters tend either to be rewarded for accepting the patriarchal order (most female heroines) or else punished for refusing to do so (most female villains). The ordeals necessary for a female character to achieve the prescribed happy ending (a family) have been interpreted as misogynistic. Commentators such as Maria Tatar point out that it is a common characteristic of fairy tales that a female protagonist must endure intolerable

12 S. S. Jones, Fairy Tales: The Magic Mirror of Imagination (Twayne, 1994) p.20

13 Compare, for instance, Tom Thumb and The Fisherman and His Wife from Grimm's collection. In the former, little Tom is eventually rewarded for managing to survive all manner of troubles (including being eaten by a wolf) where-as as the Fisherman in the other story is punished for giving to his wife's greedy demands.

14 Jones, above, at pp.27-8, 65; we shall examine the characters of Sleeping Beauty and Snow White as representatives of such protagonists below.

15 ibid., at p.66. 
abuse and degradation before she can achieve contentment. ${ }^{16}$ At least in tales involving a female protagonist, violence against and humiliation of women often appears to be central to the meaning of fairy tale justice. As we shall see, the price paid by Little Red Riding Hood (eaten by a wolf), Snow White (poisoning, choking, prolonged unconsciousness), Bluebeard's wife (attempted beheading) in exchange of their being taught a moral lesson is high indeed.

\section{Fairy tales as moral lessons in obedience, self-restraint and appreciation of family}

The story best known as 'Little Red Riding Hood' and related tales, in which a girl's mission to deliver supplies to her Grandmother's house in the woods is interrupted by a hungry wolf, is a story that has received much academic attention in terms of its implications for justice and gender. Each of the two most well-known versions - Perrault's Little Red Riding Hood and Grimm's Little Red Cap - involve an encounter between a girl and a wolf first in the forest and then at the house once the Grandmother has been eaten. In each version, the girl is shown to be partly responsible for her own and her Grandmother's ordeal, since she allows herself to be diverted from the path and unwittingly directs the wolf to her Grandmother's cottage. ${ }^{17}$ The 'moral' at the end of Perrault's version makes it clear that the 'wolf' is really a smooth-talking seducer and that the girl bears at least some responsibility for her demise: "Alas for those girls who've refused the truth, the sweetest tongue has the sharpest tooth." Grimm's version removes most of the evidence of paedophilia, leaving the barest hint of a sexual motive. ${ }^{18}$ Both versions are commonly interpreted as a warning about the dangers of immature femininity when faced with dangerous masculinity. For Christina Bacchilega, both Perrault's and Grimm's versions depict femininity as constituted by and secondary to masculinity. For example, Perrault's tale ends with both the girl and the Grandmother actually killed and eaten by the wolf, ${ }^{19}$ whilst in Grimm's tale she and her Grandmother must wait to be saved by the honourable woodcutter. In both accounts therefore, the girl is not equipped with the power to determine her own fate and is punished for her weakness. This criticism is also made by Zipes, who argues that the protagonist of Perrault's version especially is "a delicate, bourgeois type, who is helpless, naïve and culpable, if not stupid". ${ }^{20}$

Bruno Bettelheim gives a more sympathetic interpretation of the story, arguing that, in Grimm's version at least, there is a useful lesson to be learned about harnessing and restraining one's own desires in the interests of duty and safety. Little Red Riding Hood shows her immaturity in being so easily tricked by the wolf. Her subsequent punishment by being eaten is

16 See S. Sellers, Myth and Fairy Tale in Contemporary Women's Ficton (Palgrave, 2001) at p.9.

17 Grimm, n.1 above at p.134.

18 For example, the wolf says to the girl: "What are you carrying under your apron?" (Grimm, above, n.1 at p.133).

19 C. Bacchilega, Postmodern Fairy Tales: Gender and Narrative Strategies (University of Philadelphia Press, 1997) at p.58.

20 J. Zipes, Fairy Tales and the Art of Subversion: The Classical Genre for Children and the Process of Civilisation (Routledge, 1991) p.29. 
right, he argues, because by her own weakness she allowed her Grandmother to be eaten. ${ }^{21}$ The path through the woods is clearly the path of law for this little girl, and her second encounter with the wolf is the enforcement to the law. Although the consequences of her deviance from it are terrible and traumatic, they nonetheless serve only as an admonition. Unlike the archetypal wicked stepmothers who, as we shall discuss, have departed too far from the path to be brought back, Little Red Cap is given a second chance to behave. The experience of being eaten (or whatever else we are supposed to imagine) teaches girls that to practise self-restraint and obey instructions is to protect oneself from the dangers of the world. ${ }^{22}$

The importance of conformity in the fairy tale idea of justice is identifiable in many tales involving the ordeals of adolescents. In Grimm's Snow White, we are told that a childless queen wished for "a daughter, with skin as white as snow, lips as red as blood, and hair as black as ebony". ${ }^{23}$ The wish is granted before the queen dies and is replaced by another woman. As the magic mirror later insists, Snow White becomes "a thousand times more fair" than her stepmother, precipitating the events of the story. ${ }^{24}$ The significance of the story for our interest in ideas of justice lies in the identity of the authoritative voice of the mirror. Whose voice does the mirror represent? McGlathery argues that it is the voice of the queen's own vanity and narcissism. ${ }^{25}$ This view certainly makes sense, as it is natural to think of a mirror reflecting one's image and one's own anxieties about it. In this story it illustrates the queen's moral failings as one who has never been able to embrace the joys of family life, which would have brought her to see her own image in the context of her care for others. As such a character, she is incapable of regarding Snow White as her daughter in need of love, but only as a reminder of her own fading beauty. For Bettelheim, it is the voice of Snow White herself who, although initially thinking her mother is the most beautiful woman of all, becomes aware of her own beauty eclipsing her mother's. ${ }^{26}$ However, it is also possible to regard the mirror as having a constitutive effect upon the characters. Bacchilega argues that, as the voice of truth, the mirror frames, not just the queen's image, but that of femininity generally according to patriarchal lines. "[I]t is a patriarchal frame that takes the two women's beauty as the measure of their (self) worth, and thus defines their relationship as a rivalry". ${ }^{27}$ It is the narrator of the "truth' of womanhood: that beauty is everything, and the relationship between women is one of rivalry. I would agree that the voice of the mirror is an important framing device for the story. Bacchilega's analysis is spot-on in showing how the mirror speaks for the women. However, I would suggest that the mirror's presumed neutrality, its role as mediator between characters that it constitutes as rivals, and as a provider of a criteria for judgment means that it

21 Bettelheim, B. The Uses of Enchantment: the meaning and importance of Fairy Tales (Thames \& Hudson, 1976) at p.173.

22 ibid., at p.182.

23 Grimm, above, n.1 at p.215

24 ibid., at p.219, 20, 21.

25 J. McGlathery, Fairy Tale Romance: The Grimms, Basile and Perrault, (University of Illinois Press, 1991) p.122.

26 Bettelheim, above, n.21, at 207.

27 Bacchilega, above, n. 19, at p.34. 
is in fact the voice of law. It determines the criteria of judgment and the relationships between the characters. Enforcement of the law in this case distinguishes between admonition and execution. Firstly Snow White, although showing weakness in allowing herself to be tricked into disobeying the dwarves' injunction on her not to open the door to strangers must endure three apparent deaths and a lengthy spell in a comatose state before she can awaken a new woman. Before this occurs, Snow White herself shows herself to be dangerously narcissistic. ${ }^{28}$ The reason why the jealous queen so easily overcomes her three times is because Snow White is herself obsessed by her own beauty and therefore cannot resist the items that may make her look even more so. ${ }^{29}$ However, unlike her stepmother, she is not beyond correction. When the girl is apparently killed by the poisoned apple she has entered the chrysalis-like state common to various other tales necessary in order to be reborn chastened and ready to obey and serve a husband (the prince who finally rescues her). ${ }^{30}$ Bettelheim imbues his own analysis with an empowering interpretation: his female characters are "twice-born" in order to gain the independence and wisdom to deal with "future wolves". ${ }^{31}$ For Bettelheim, the transformation of girl to woman simply represents the learning curve of adolescence. Of course, a more critical reading would seek to examine the nature of the lesson learned here: is it independence and empowerment or is it merely obedience? On the other hand, the queen, eaten up by her own jealousy can expect nothing but death, and by the cruellest of means.

There are other variations on the Snow White theme that appear in Grimm's collection. The Almond Tree, for instance, also involves the creation of a child that, like Snow White, reflects the purity of nature. During wintertime, a childless woman cuts her finger while standing under her Almond Tree. Watching the drops fall on the snow she says: "if only I could have a child as red as blood, and as white as snow".32 The natural environment and childbirth are presented as unified in the shedding of blood and the passing of the months, during which the tree bears its fruit and the woman bears the child she desires. In this tale the child born is a boy with skin as white as snow, and when his mother dies he is brought up by his doting father and jealous step-mother. Unlike Snow White, there is just one (patently successful) attempt by the stepmother to murder the boy when she cuts off his head by slamming a chest-lid down on his neck. She cooks the body for her husband's dinner and afterwards his bones are laid under the Almond Tree. As a confirmation of the irrepressibility of natural life, the magic tree has the boy resurrected as a beautiful bird that finally takes its revenge on the stepmother. We are clearly supposed to believe that the stepmother deserves her fate because she did not respect the natural cycle of life represented by the Almond Tree (that Bacchilega would presumably interpret as patriarchy). The Almond Tree represents all that is natural, whilst the stepmother, like most of her kind in fairy tales, cannot bring herself to leave behind her childish egocentricity and accept the natural order of things. Unlike Snow

28 Bettelheim, above, n.21, at p.203.

29 ibid., at p.209.

30 ibid., at p.213.

31 ibid., at p. 183

32 Grimm, above, n.1, at p.186 
White the boy is simply an innocent, and is allowed to take his own revenge on his stepmother. It is no coincidence that he chooses to do so by dropping a millstone on her, physically reflecting and hence balancing the injustice done to him. ${ }^{33}$ The more passive Snow White must content herself by watching the prince's choice of torture and execution of the stepmother queen at their wedding, at which the latter is made to dance on red hot iron shoes until she falls down dead.

The story of Sleeping Beauty and the many other related tales found in European sources forms another example of the inevitability of the reproduction of life, and family life in particular. Typically conservative, Bettelheim reads this tale as being about a father paralysed with anxiety over the unavoidable fact that his little girl will one day grow into a woman and leave him. Despite his meticulous efforts, he cannot prevent the coming of age of his daughter: the pricking of her finger and subsequent bleeding representing the inevitable beginning of womanhood and sexual awakening. ${ }^{34}$ It is easy to regard this story as it is interpreted by Bettelhiem's view as another affirmation of the status quo: a girl cannot be protected from discovering her true role as a woman in the joys of marriage and children. Grimm's The Sleeping Beauty is predated both by Perrault's The Sleeping Beauty in the Wood and Basile's Sun, Moon and Talia. ${ }^{35}$ The latter especially contrasts the sheer force of heterosexuality and family life against the futility of the father's efforts to prevent it and the passivity of the female protagonist. In Basile's story, when the heroine (called Talia) 'dies' as prophesised, her heartbroken father-king immediately leaves the kingdom forever. ${ }^{36}$ As in Snow White, feminine beauty is here associated with passivity and surrender since the prince's desire is stirred by the girl's silence and stillness. ${ }^{37}$ However, whereas in Grimm and Perrault, the princess is awoken by a prince's kiss, ${ }^{38}$ Basile has a passing king make love to the girl's lifeless body and thereby impregnating her. ${ }^{39}$ Remaining 'dead' throughout, Talia later gives birth to twins (called Sun and Moon) who eventually bring her back to life by sucking the poisoned hemp from her finger. Whereas Grimm ends with the awakening and marriage, Perrault and Basile both depict the girl's continuing troubles involving her lover's jealous wife (Basile) or mother (Perrault). Predictably, the patient, docile beauty of the young girl is rewarded at the expense of the queen whose beauty is fading and is consumed with murderous jealousy. In Basile's story, the queen demonstrates her resistance to the patriarchal order by inducing the secretary to act contrary to his alliance to the king in helping her to kill Talia and the children she gave birth to whilst asleep. The queen is therefore not only guilty of attempted murder, but also treason. She has what she thinks is the

33 ibid., p.195.

34 Bettelheim, above, n.21, at p.232-3.

35 Basile, above, n.3 at pp.372 - 376. See also http://www.pitt.edu/ dash/type0410. html\#basile.

36 Basile, above, n.3 at p.373: “. . . and closing the doors, being desirous to forget all and to drive from his memory his great misfortune, he abandoned for ever the home wherein he had suffered so great a loss."

37 See Bacchilega, above, n.19, at p.35.

38 Grimm, above, n.1, at p.208.

39 Basile, above, n.3 at p.374: "[He] carried her to a bed, whereon he gathered the first fruits of love..." 
children cooked and served to her cheating husband. The queen is eventually punished by being burned to death in the fire that she had herself prepared for Talia. ${ }^{40}$

We may presume that the jealous wife of Sun, Moon and Talia got what she deserved. The patriarchal order must be respected even if this means accepting that one's husband will not be true to his wife. A 'good' woman maintains quiet dignity in the face of her husband's indiscretions. This does seem to fit with the picture of femininity as synonymous with silence painted in the Snow White and Sleeping Beauty stories. In treating her husband's infidelity as a personal insult worthy of calculated and cruel retribution, Basile's queen has effectively attempted to create a different moral scheme that threatens an existing one. This is unacceptable and so the queen must be eliminated. We should also note that the jealous queen in Sun, Moon and Talia has herself not borne the king any children. When she watches her husband eating what she thinks is his children's flesh, she informs him that the meat he is eating is 'his own'. The king's retort is equally suggestive: "I know very well I'm eating what's my own, because you have brought nothing to this house." 41 Thus the appearance of Talia and her two children contrasts against the queen's own failure to do her duty as a woman and a wife. ${ }^{42}$ The bourgeois ideal, of course, is productivity and reproduction of family life in accordance with nature. The queen has not only failed to produce any children of her own, but has jealously and cruelly attempted to kill those of the king. She clearly represents the very opposite to the ideal of family life and is therefore fit for nothing but the flames.

Perrault's Bluebeard is one of a number of folk and fairy tales in which the heroine's prize for surviving an ordeal is not marriage, but escape from death at the hands of a powerful and brutal man. Amongst the nastiest of the European tales, they all share the theme of a woman's discovery that a certain man is a misogynistic serial killer and intends to kill her. They all follow one of two possible plot-lines. One form, (including Perrault's Bluebeard and Grimm's Fetcher's Fowl the woman discovers this through succumbing to the temptation of entering a room from which her husband has forbidden her, and therein discovering the bloody corpses of his previous wives. $^{43}$ The other form (including the English tale Mr Fox, the American Pretty Polly and Grimm's The Robber Bridegroom) involves a woman making a journey to the house of a man she does not know well (sometimes her suitor or fiancé) where she witnesses him killing a woman in a sexual or cannibalistic ritual. Commentators have suggested that at the very least the stories represent female anxiety about marriage and the consummation of marriage. ${ }^{44}$ Warner identifies fear of childbirth, until the advent of antibiotics and anaesthetics a very real danger for women, as the warning intended for peasant women in the original folktale: "In the forbidden chamber, Bluebeard's wife had perhaps found herself face to face with the

40 ibid., at p.376.

41 ibid., at p. 375.

42 Warner, above, n.10 at p. 220.

43 Perrault, above, n.2; Brothers Grimm, Selected Tales, trans. D. Luke (Penguin, 2004) pp.362 - 365

44 McGlathery, above, n.25 at p. 55. 
circumstances of her own death". ${ }^{45}$ A strong theme in Perrault's version is that the woman brings disaster upon herself by her own curiosity and inability to obey instructions. It is possible that, as a folk tale that existed long before Perrault's version was published in 1697, it was told amongst the peasantry, either as depicting the dangers of curiosity and temptation generally, or as a specific response to the case of the French nobleman Gilles de Rais who confessed to the killing of 140 boys near his home in Brittainy in 1440 . Bettelheim predictably interprets the story as being primarily about the consequences of a woman's sexual transgression and subsequent guilt. In both Perrault's Bluebeard and Grimm's Fetcher's Fowl, the woman's disobedience is discovered because she drops a magic object entrusted to her which becomes indelibly stained with the blood of the previous victims. The tell-tale bloodstains on the key (that Bluebeard entrusts to her and forbids her from using) and on the egg (that the sorcerer compels the women in Fetcher's Fowl to always carry) are the signs of her defloration by another and her guilty conscience. ${ }^{46}$ Christina Bacchilega argues that the woman is no passive victim, but her energy is not directed constructively. Instead she is self-destructively drawn towards a man (Bluebeard) by his riches, power and physical strength despite being repulsed by his appearance and despite knowing that he has been married several times to women, all of whom have mysteriously disappeared. Perrault's story makes it clear that she suspects the worst by the fact that she instructs her brothers to be ready to rescue her if needs be. In Grimm's The Robber Bridegroom and related stories, the woman travels to and ventures inside her bridegroom's house despite repeated warnings that by doing so she is putting herself in mortal danger. Significantly, one such warning is issued by the bridegroom himself - "My house is a long way in the wood" 47 - a warning familiar to fairy tale readers accustomed to the inside/outside distinction denoting safety and danger respectively. In the closely related English folktale $\mathrm{Mr}$ Fox, the woman ventures into her suitor's castle despite being warned: "Be bold, be bold, but not too bold, lest your heart's blood should run cold." Bacchilega argues that the woman shows herself to be complicit in that which victimises her. ${ }^{48} \mathrm{Her}$ adventurousness, curiosity and economic dependence are all directed towards her near-death experience. ${ }^{49}$ Angela Carter's modern retelling of the story in The Bloody Chamber also preserves the theme of female masochism. Her version emphasises the husband's power over her in every respect, and her acceptance of this. Unnamed as in Perrault, she describes herself as sexually objectified by him, and as one of his jewels on display: "I wore a sinuous shift of white muslin tied with a silk string under the breasts. And everyone stared at me. And at his wedding gift". ${ }^{50}$ The wedding gift happens to be a "choker of rubies, two inches wide, like an extraordinarily precious slit throat", surely a macabre warning of what may be to come. ${ }^{51}$ On the

45 Warner, above, n.10 at p.263.

46 Bettelheim, above, n.19 at pp.300-1.

47 Grimm, above, n.1 at p.174; the David Luke's translation for the Penguin edition is even more chilling: "My house is out there in the dark forest."

48 Bacchilega, above, n.17 at p.129.

49 ibid., p.138.

50 A. Carter, 'The Bloody Chamber' in Burning Your Boats: Selected Short Stories (Vintage, 1995) pp.111-143 at p.114.

51 Bacchilega, above n.17 at p.123; Carter (ibid) at p.121. 
wedding night she is "impaled" by him in love-making. There is surely nothing empowering for femininity in Carter's prose.

Our review of fairy tales involving female protagonists and subsequent critical literature would suggest that interpretation cannot avoid the intersection between justice and gender. On this reading, justice is served by ensuring that characters that can be educated to accept and value the ideal of productive family life are eventually rewarded. Those that cannot be educated must be eliminated. The 'justice' meted out in the fairy tales is a demonstration that the replication of family life is irrepressible. Although politically very different, Bacchilega's and Bettelheim's views both attest to the rigidity of the educative moral narrative. All the female protagonists of these fairy tales necessarily endure a greater or lesser ordeal at the hands of a cruel villain, suffer a quasi-death, and then are reborn as better, contented adults. The problem with Bettelheim's analysis is that it implies a meek acceptance of the status quo. Bacchilega's problem is that she can only account for the morality of desert as patriarchal. I suggest that the moral order and thus the fairy tale idea of justice is a broader notion of 'law' as a structure of normativity with its own method of enforcement. The natural order implied in the tales indicates that the moral norms are treated as rules (characters either already know or are made to learn them) and these rules are backed by threats of force. The criteria for judgment is objectively determined by the moral order itself and is not open to negotiation by the characters themselves. The voice of law features in all of the tales examined here: we find it in the character of Bluebeard who tries to enforce his will on his wife; in the path through the woods that Little Red Cap must duteously follow and not veer from; in Snow White learning to be obedient. It is this law that is determinative of a character's place within the moral hierarchy of fairytale justice. It is sometimes broken - both Little Red Cap and Snow White's stepmother break the law in their own way - but it is always enforced. Transgressions are punished and the severity of the punishment depends upon the possibility of the offender being brought back within law's parameters. Where a character is beyond redemption then only the death penalty can be appropriately severe. Law's 'others' must learn to forget their otherness by accepting and obeying the rules. Difference as such is accounted for only by the jealousy, selfishness, narcissism and cruelty of stepmothers and wives, who, being beyond redemption have only humiliation and death to look forward to.

\section{In Search of Justice: Deconstructing the Moral Hierarchy}

Our foray into the justice of fairy tales as a moral hierarchy would seem to show a clear distinction between the prioritised 'inside' where the safety and domestic order is maintained, and the 'outside', the latter being the proper place for wolves and stepmothers. Violence of varying degrees is used by the heroes and heroines of the tales to ensure that justice is appropriately done..$^{52}$ Thus Grimm's hungry wolf is repaid for his voracious appetite by having his belly filled up with heavy stones. The beauty-obsessed stepmother queen is disposed of by being made to dance in red-hot iron

52 M. Tatar, The Hard Facts of the Grimm's Fairy Tales (Princeton University Press, 1987) p.183. 
shoes. ${ }^{53}$ The queen whose heart burns with jealousy for her husband's lover in Sun, Moon and Talia is burned in the fire that she prepared for her victim. As Tatar argues, to forgive the villains would leave the stories with a grave moral imbalance. ${ }^{54}$ Indeed, the punishment of wrongdoers may be regarded as a moral imperative. Liberal retributivists argue that the pain suffered by an offender is a thing of value in itself. ${ }^{55}$ If offenders go without punishment then there is no acknowledgment that the offender was responsible for his or her own choices, ${ }^{56}$ and there is no redress for the injury suffered by the community. ${ }^{57}$ Although doubtlessly cruel, it may be a little problematic to accord full responsibility to villains for their actions if we are to accept Bacchilega's insistence of the determinative power of patriarchy.

However, the violent punishments meted out on the fairy tale villains also protect the integrity of patriarchal moral authority. Certain analyses of law, such as that of Peter Fitzpatrick, suggest that law's violence is legitimised by its being proportionate, necessary and in accordance with pre-determined parameters - in opposition to the uncontrolled, 'savagery' of illegitimate violence that knows no rational limits. ${ }^{58}$ In fairy tales, the choice of punishment is a retrospective balance and a restoration of the natural moral order. Since the 'moral' of many fairy tales is that a particular villain brought punishment upon themselves by knowingly transgressing accepted norms, it is arguably proportionate and pre-determined in the sense that they are treated as appropriate responses to the villain's previous wickedness. Thus, fairy tale punishment makes its own appeal to legitimacy. In law, the necessity of force is demonstrated by the need to protect the integrity of the system itself: criminal wrongs between people are also wrongs against the system and these must be punished in order for the system to remain effective. Likewise, the legitimacy of the use of violence against the villains of fairy tales depends upon its necessity in protecting the safety and integrity of the home from outside threat. Justice in this sense requires constant vigilance in defending the border between a conceptual 'inside' (home, safety, order, family, familiar) and outside (danger, disorder, unfamiliar). This section comprises a detailed critical examination of this moral distinction between interiority and exteriority and argues that there is more at play in the narratives than a mundane replication of bourgeois family values. Rather than bolstering this moral integrity, the violence threatened and inflicted in fairy tales actually undermines it.

53 Grimm, above, n.1 at p.224.

54 M. Tatar, The Hard Facts of the Grimm's Fairy Tales (Princeton University Press, 1987) p.181.

55 H. L. A. Hart, Punishment and Responsibility: Essays in the Philosophy of Law (Oxford University Press, 1978) p.8.

56 A Duff and A von Hirsch, 'Responsibility, Retribution and the 'Voluntary': A Response to Williams' (1997) 56(1) CLJ 103 at 110-112.

57 R. A. Duff, 'Punishment,Communication and Community' in M. Matravers (ed) Punishment and Political Theory (Hart Publishing, 1999) p.61.

58 Fitzpatrick, P. The Mythology of Modern Law (London and New York, N.Y., Routledge, 1992) p.81. 


\section{Re-reading fairy tale gender stereotypes}

The gender roles depicted in the 'official' published tales should not be read as indicative of universal truths. The folk tales that had existed in oral form since the Middle Ages were interpreted by Grimm, Perrault and Basile in the context of their respective social conditions. In removing details that they considered unsuitable for their middle class audience, and imbuing the tales with their own cultural values, Grimm and Perrault were both collectors and authors. Zipes describes the Grimms as "bourgeois missionaries" in this respect. Comparing the Grimm's earliest manuscripts with the 1812 printed edition, Zipes concludes that "each and every oral tale was conscientiously and, at times, drastically changed". 59 Viewed as such, we can challenge the gender assumptions of the morally weak woman of, say, the Bluebeard-type tales by applying a different emphasis. Bacchilega does so by insisting that the tale is really all about a woman daring to defy her husband in order to acquire knowledge, and her triumph over death through bravery and mobilisation of family alliances. ${ }^{60}$ Warner argues that other versions of the story (e.g. a nineteenth century story by Italo Calvino called Silver Nose) emphasise, not the inability of the woman to resist temptation, but the way in which "quick witted female double dealing overcomes the tyrant". ${ }^{61}$ Thus it is possible to shift the focus from the wife's indiscretion to her daring escape that is central to Grimm's The Robber Bridegroom. "Female disobedience is hardly the point", writes Bacchilega. ${ }^{62}$ However, Bacchilega maintains her thesis that the wife's masochistic, curious and daring character makes her complicit in her ordeal. This makes it difficult to interpret the Bluebeard tales. On the one hand it leaves the essentially conservative macho male fantasy that even strong, intelligent women will throw away their own independence and autonomy for a powerful man. However, her cool cunning, determination to acquire riches and above all her drive to gain knowledge suggests not a weak victim but a worthy adversary for her husband. Both male and female characters in the Bluebeard-type tales are preoccupied in attempting to gain power and advantage over the other: Bluebeard and the Sorcerer of Fetcher's Fowl do so by entrusting their respective women with a task requiring a degree of self-restraint that they expect not to be achieved. The women do so by daring to defy a man that regards himself as law.

In The Robber Bridegroom, the heroine is so determined to discover the truth about her bridegroom that she ignores all the warnings given to her. In the previous section we suggested that this might represent the masochistic female desire that Grimm and Perrault wanted to show to be in need of tutoring and taming. These tales arguably function to warn women against attempting to acquire knowledge that they are unable to cope with. This argument might carry some weight in the case of Perrault's Bluebeard where the wife may not have been in danger had she obeyed her husband and resisted temptation, but in The Robber Bridegroom and related tales there is no such opportunity, since the man kills simply because he is a sadistic

59 Zipes, Fairy Tales and the Art of Subversion, above, n.20 at p.49.

60 Bacchilega, above, n.17 at p.107-9.

61 Warner, above, n.10, p.257.

62 Bacchilega, above, n.17 at p.111. 
misogynist. It is vitally important for her own survival that the woman learns what he is really like. Her perseverance does not come from a selfdestructive will then, but from bravery and strength of character. We would also have to concede that the function of the key (Bluebeard) and egg (Fetcher's Fowl) is undecidable in terms of determining the just deserts of the female protagonists. Unlike Oedipus, for whom discovery of the whole truth brought inevitable disaster, the female protagonist in these tales is rewarded for her troubles by retaining the husband's riches, as she always desired. Her apparent character flaws of failure to resist temptation and attraction to danger are also her character strengths, as they are necessary for her to learn about the world in which she lives, and hence for her acquisition of power.

Both the villains and heroes of the Little Red Riding Hood motif can be deconstructed by considering the tale in its specific, historical context. For instance, a traditional Italian folk tale (written down in Italo Calvino's The False Grandmother ${ }^{63}$ ) has the girl being tricked by the wolf into eating her Grandmother's boiled teeth ("beans") and fried ears ("fritters"), stripping and getting into bed with him. Perrault and Grimm also altered the scope of the gender roles. Calvino's version credits the girl with far more intelligence and resourcefulness than did Grimm or Perrault. For instance, the famous exchange between girl and wolf girl on the 'Grandmother's' strange physical appearance (which is common to all versions of the tale) leads, not to her being eaten, but to her concluding that, being so physically strange ("why is your chest so hairy, Grandmother?"), the thing in the bed cannot be her Grandmother. Calvino then has the heroine excusing herself to defecate in the barn below the cottage, before making her escape and then finally killing the beast as it tries to pursue her. Nor does Calvino suggest that the girl is herself to blame for the events. His version lacks the initial encounter in the forest in which the girl implicates herself in the wolf's crime by directing him to her Grandmother's house. Instead, her journey to her Grandmother's house has her making peace offerings to a gate and a river from her basket, which in return later help her to escape. Perrault's decision to have her finally eaten and Grimm's to have her rescued by the woodcutter significantly alters both the tale's theme from a brave girl's adventure to moral correction, and its view of the proper level of activity for a female character.

Nor is the Grandmother all that she seems. The Grandmother of Little Red Riding Hood is supposed to represent the end point of the mission that the girl's Mother sends her on. But instead of finding the safety of home from home, she finds the wolf waiting to eat her up. As we have discussed, the Red Riding Hood of Grimm and Perrault has unwittingly directed the wolf there and the Grandmother invited him in. However, is it possible that the wolf was already living the cottage before the story's events unfold? Whereas in Grimm and Perrault, the wolf and Grandmother are clearly different characters, Angela Carter's story The Werewolf suggests that the wolf is actually part of the family, specifically, that the wolf is the Grandmother: that she is a Werewolf. ${ }^{64}$ In Carter's story, instead of straying from the path

63 http://mld.ursinus.edu/Maerchen/false.html.

64 Carter, above, n.50, p.210 - 211. 
and naively directing the wolf to deal with her Grandmother, the girl bravely and competently fights it off with a hunting knife, cutting off its front paw. When she gets to the cottage she discovers her Grandmother's true identity by the tell-tale bloody stump where a hand should be and duly has the werewolf killed. Angela Carter's story alludes to the historical fact that remote peasant communities of the late Middle Ages Europe lived in fear of wolves, and that popular association between wolves and the devil sustained a belief in werewolves. Records indicate that it was not uncommon in the sixteenth and seventeenth centuries for an accusation of being a werewolf to be used as a form of scapegoating. ${ }^{65}$ Can we not read Little Red-cap's own perception of wolf-like qualities in her Grandmother ("what large hands you have got!" 66 ) as a dawning awareness that "family' does not always mean 'safety'? It would be mere comedy if the girl were actually to confuse her own grandmother with a wolf wearing her nightcap and glasses. The literary critics of the 1970s wondered why the Grandmother is so easily tricked into letting the wolf into the house when she ought to know better; why she dressed the girl up coquettishly in a pretty cap (for it was a present from the Grandmother); why, further, the mother sends her out into the forest so ill prepared to deal with its dangers. Those critics put it down to Oedipal anxieties and the dangerous naivety of female sexual curiosity and masochism. Zipes and others dismiss such psychoanalysis as "banal, superficial observations" about sexual desire, violence and power ${ }^{67}$ which reduce the tales to "material for pop psychology self-help books" ${ }^{68}$ In the light of Carter's version the guilty sexual desires analysis is not necessary. Little Red Riding Hood is a tale about family life and the fears of peasant communities. In this light, the black comedy of the girl's examination of Grandmother's physical peculiarities becomes a horrific lesson that one's own family might not necessarily have one's best interests at heart.

Some commentators argue that this way of reading Little Red Riding Hood as a warning about violence in the home should be applied also to the stepmother character in other tales. It is Zipes's view that the wickedness of the stepmother may in fact represent, not the opposite of normal family life, but the family as itself a scene of violence and abuse. ${ }^{69}$ Zipes argues that the Grimms wanted to warn of the abuse of children within the family home. The woman who abandons, neglects, abuses or attempts to murder the children of a family is in fact the children's real mother. McGlathery supports this, pointing out that in the original Grimm version of Snow White, the jealous woman is Snow White's mother. ${ }^{70}$ The 'step' mother is thus superimposed by Grimm onto the simpler nuclear family as a literary device for allowing the abuse to be spoken of without utterly destroying the moral integrity of family. ${ }^{71}$ Therefore, for Zipes, the stepmother character stands for the dangers that children face within the family. Zipes's view carries the troubling implication that the innocent, beautiful adolescent of the fairy tales

65 Zipes, Fair Tales and the Art of Subversion, above, n.20, at pp.28-9.

66 Grimm, above, n.1 at p.135.

67 Zipes, The Brothers Grimm, above, n.4 at p.117.

68 ibid., p.118.

69 ibid., p.120-7.

70 McGlathery, above, n.25 at p.122.

71 Zipes, above, n. 4 at p.121. 
may naturally mature to become the frustrated, narcissistic mother that turns on her own daughter in envy. The 'norm' may therefore not be the 'happily ever after' of lifelong, happy marriage and childrearing, but an arena of cruel torture and death. Thus, we might discern a twist to the generally assumed static prioritisation of family over egocentric values. It is the family itself that is shown to be the site of violence, but this is too horrible to be narrated without the dissociative artifice of the 'step' mother. ${ }^{72}$

Thus, the issue being raised in these tales is not the outside threat that the 'step' mother poses, but the threat faced by children already within the family. However, as Marina Warner argues, it is also possible that the stories reflect inter-generational strife within the family. Warner argues that the peasant folk tales that formed the sources for Grimm's and Perrault's official texts had survived since Middle Ages Europe through oral transmission by older women, who narrated the conflicts between younger and older generations. Oral folk tales served as a reminder to the youth of the continued power of the elders over younger family members who may be tempted to marginalise or even desert them. Marina Warner describes how, until the nineteenth century, the English word for step mother carried the same meaning as mother-in-law, and both labels carried the semi-sinister implication that the woman was not a mother by nature. ${ }^{73}$ The cruelty of the fairy tale 'step' mothers towards step-daughters or daughters-in-law is to be associated with the older women's anxieties about becoming dispossessed after the death of their husband and redundancy in society. ${ }^{74}$ In the context of a society in which widows were expected to be cared for by their son's family, resulting in large scale destitution of older women who may have never married, the tales as passed on orally by women serve to warn of the "bitter conflicts within the romance of marriage" 75 She acknowledges that the quasi-feminist depictions of older women in the oral folk tales did not survive the transition from the peasantry to their eventual 'official' form in Grimm and Perrault. The latter turned the historically specific accounts of women's inter-generational rivalry into a general demonisation and an antithesis to the feminine ideal.

\section{Other dangers in the home}

A related point is that the Sleeping Beauty-type tales that feature a fatherdaughter relationship depict not simply the already-discussed fatherly anxiety regarding his daughter becoming a woman, but in also the threat to family stability by the father's incestuous desire for her. Bettelheim is typically alert to the possibility that the father-king that leaves the kingdom and his daughter forever and lover-king that discovers her in Basile's story could in fact be the same person, although for Bettelheim this merely reflects the childish Oedipal desire of girls to seduce their father. ${ }^{76}$ However, such a desire on the part of the girl is manageable within the moral context of the

72 Bettelheim remarks that this dissociative device is used by children who invent an imaginary 'step'mother in order to cope with the fact that his or her own mother may not always behave in a loving or caring manner.

73 Warner, above, n.10 at 219.

74 ibid., p.229.

75 ibid.

76 Bettelheim, above, n.21 at p.228. 
fairy tale because it is just a complex to be worked through on the road to maturity. McGlathery's suggestion that the central theme is not the girl's but the father's desire is altogether more problematic because it threatens to destroy the family as a place of safety. Why does the father-king of Basile's story disappear from the narrative so suddenly when his daughter 'dies' as prophesised? McGlathery suggests that it is because he is afraid that he will be tempted to violate her body. ${ }^{77}$ We might also wonder why the father-king is so anxious to prevent the onset of the inevitable in the first place. If we accept Bettelheim's and McGlathery's interpretations of the father's anxieties to prevent to loss of his daughter to womanhood then it is arguable that the distinction between father and lover is blurred to the point of undecidability. By the father's incestuous desire and the source of violence against children being locatable within the family itself, the status of the family as a place of order and harmony becomes more problematic still.

Given the apparent preoccupation in tales of the 'Snow White' and 'Sleeping Beauty' type with the inevitability of replication and productivity of wholesome family life, it should perhaps not be surprising that we find incest represented. The link between the natural cycle of life and death and incestuous desire lies in male anxieties about loss: a man whose wife dies young is physically reminded of her by their child At the same time he is anxious that the daughter borne by his deceased wife is fast growing up and will one day leave him. Interpreters of the fairy tales have tended to suggest that the memory of losing the wife coupled with the anxiety about imminently losing the daughter to womanhood and marriage motivates a sexual desire in the father for his adolescent daughter. We have seen how the 'birth' of Snow White is precipitated by sexual desire ("skin as white as snow, a mouth as red as blood") and accompanied by the death of the mother. The drops of blood that the queen watch falling onto the snow are representative both of sexual reproduction and of Snow White's physical appearance (and in being called 'Snow White', this is constitutive of her very identity). It is not surprising, then, that Angela Carter's modern retelling has the newly created snow-child raped by the Count at the end of the story. ${ }^{78}$ In Basile's Sun, Moon and Talia, the mother of the girl is simply absent, presumably having died in childbirth. The absence of a mother makes the daughter the only representative of femininity in the tale, and thus it is understandable that the king is, first, so anxious not to let her go, and second, so heartbroken at his failure to prevent the inevitable.

McGlathery argues that the relationship between the king and the princess makes the 'Sleeping Beauty' type tales comparable to those in which the incestuous desire of a father for his daughter is made explicit. Tales in all three major collections involve fathers who desire their daughters because a dying wife implicitly condones or even requests it. Grimm's Cat-Skin and Perrault's equivalent The Donkey's Skin both involve a dying queen making her husband-king promise never to remarry unless he finds someone quite as beautiful as she. ${ }^{79}$ In both the tales, the initially inconsolable king eventually

77 McGlathery, above, n.25 at p.99.

78 Carter, above, n.50, pp.193-194, 'The Snow Child'.

79 See The Brothers Grimm, Household Tales (Dent \& Sons, 1953) pp.215 - 220 at p.215. 
realises that the only woman who can match his dead wife's beauty is his own daughter, and ignoring dire warnings from his courtiers, tries desperately to have her. Both tales show the daughter driven into squalid hiding in order to escape her father's amorous advances. Disguised in rags, she becomes a servant at the palace where she coyly allows herself to be discovered by a Cinderella-type plot device (involving a gold ring that she drops into the king's soup) and readmitted into royal society. Perrault's tale makes more moral sense than Grimm's, ending with the girl's marriage to a prince and her forgiving her repentant father. Incredibly, Grimm's tale ends 'happily' with the princess entering fully into the role of her father's wife. The delighted king, who seems to have forgotten the identity of this girl, exclaims: "You are my beloved bride, and we will never more be parted from each other." 80 Is it possible that the sleeping beauty theme is related to these tales of fatherly incestuous desire? Furthermore, can justice for the protagonists of these fairy tales really incorporate necessary exposure to incest and abuse? If we were to accept that bad things befall good people in order that they can mature then we could say yes - it is still just that they are 'rewarded' with the flawed prize of such domestic ordeals. If, as McGlathery argues, Sleeping Beauty is to be associated with the incest tales, then the moral significance of these tales is that the prize is not pure or innocent and the family is no longer simply the site of productivity and new life.

\section{Conclusion}

However we choose to interpret the tales examined here, the only certain thing is that the juxtaposition of safety to danger, good to bad, aggressor to victim, etc, is not a clear distinction. Of course, the destabilising of hierarchical oppositions means that a simple definition of 'justice' as it is presented through the medium of fairy tales actually seems further away. The ideal of the home that is defended against threats from outside is undermined by the ambiguities of characterisation. Principally, the distinction between inside and outside as indicators of moral order (and thus of justice) come under threat from within. How can one shut the door of the family home against the dangers of the forest when those dangers are always already inside the house? The protective measures displayed in the fairy tale narratives are deployed to do just that, but since the danger is already inside, such measures are reduced to mere covers for the source of the threat. Thus a mother who feels murderous jealousy because of her daughter's superior beauty is distanced from the family by being cast as a stepmother. The wolfish traits of one's own family members are disguised in the narrative by creating the character of the wolf and locating him outside in the forest.

80 ibid., p.220. 